CHAPTER 9

\title{
Patroclus was a Parasite
}

\author{
Lucian's Satirical Aitia
}

Inger N.I. Kuin

'No one knows so little of Homer, so as not to know that the best of the heroes are parasites' (Par. 44). This bold claim comes from Simon, an interlocutor in a dialogue by the second century CE author Lucian of Samosata, titled De parasito (On the Parasite). Simon's argument in this piece is that the parasitic art deserves to be considered a techne because the Homeric heroes invented the practice. De parasito is a clear parody of the genre of encomium, but it also takes aim at the efforts of myth rationalizers, from Prodicus (fifth century BCE) to Heraclitus (second century $\mathrm{CE}$ ), to explain (origin) myths by explaining the origins of origin myths. In this chapter I will argue that De parasito, together with such pieces as De saltatione (On the Dance), De astrologia (On Astrology), Electrum (Amber), and Muscae encomium (Praise of the Fly), represents Lucian's playful response through parody to rationalizing aetiologies of myth.

Myth rationalizers test myths against the standards of probability and plausibility of the present, and reinterpret or alter them to fit such standards. ${ }^{2}$ Arguing, for instance, that it is impossible that Atlas carries heaven on his shoulders, they maintain that he was among the first astrologers. Similarly, Medea was not really a sorceress but rather an inventive and entrepreneurial

1 I would like to thank the editors of this volume for their comments on earlier drafts of this chapter, as well as Richard Hunter for his help with the paper from which this chapter derives. I have presented this work at the CRASIS Annual Meeting at Groningen University in 2016 and at the Venice International University Advanced Seminar in the Humanities 2014; I thank the audiences at both conferences for their insightful comments and questions. Greta Hawes kindly shared the proofs of her book on myth rationalization with me, which was not yet published when I first started this project (Hawes 2014). This chapter has been written with the support of the Anchoring Innovation research project. Anchoring Innovation is the Gravitation Grant research agenda of the Dutch National Research School in Classical Studies, OIKOS. It is financially supported by the Dutch ministry of Education, Culture and Science (NWO project number 024.003.012). For more information about the research programme and its results, see the website www.anchoringinnovation.nl.

2 Hawes 2014, 2sq. See also Hugo Koning's chapter in this volume. 
beautician. ${ }^{3}$ The tendency to reinterpret gods and heroes as human 'first inventors' goes back to Prodicus and, later on, Euhemerus (third century BCE). Lucian puts this motif on its head by applying it to lowly pursuits like parasitism, or by expanding the number of first inventors to ridiculous proportions. Both the practice of myth rationalization and the application of the first inventor motif specifically originated several centuries before Lucian's lifetime. Nonetheless, in the second century CE several authors produced myth rationalizations, using also the first inventor motif; two relevant authors from the period whose works have been preserved are Pausanias, the well-known travel writer, and the much less known writer Heraclitus the Paradoxographer (not to be confused with the natural philosopher from Ephesus). Lucian's parodies should be read as a response to these kinds of texts, and thus as an engagement with one of the trends of the literary culture of his day.

I will start this chapter with a discussion of the efforts of myth rationalizers generally and Lucian's distortions and parodies of these efforts. Next, I will focus on the first inventor motif and its application by Lucian's contemporaries, as well as Lucian's humorous response to them. With his satire Lucian exposes the double bind that troubled myth rationalizers: on the one hand, they wanted to stay true to their standards of plausibility, on the other hand, they wanted to salvage the mythical and aetiological traditions - the very fabric of Greek culture and therefore seen as intrinsically valuable - as much as possible. As a result, many of their 'rational' explanations are scarcely more credible than the myths they were meant to explain in the first place. I argue that Lucian's parodies aim to show that the rationalizers fail to understand the difference between everyday causality and mythical causality: unlike methodical, proto-scientific explanations from historiographical or medical writing, mythical narratives can be true even if they are unlikely (cf. also Klooster in this volume). Lucian playfully exposes the futility of trying to explain the origins of origin myths, which ultimately amounts to aetiologizing aetiologies.

\section{Lucian and Myth Rationalizers}

In her recent monograph on the subject of myth rationalization Greta Hawes has emphasized that this method is not in principle antagonistic to myth. Practices of questioning, appropriating, and even altering myth are embedded

3 The first example comes from Heraclitus the Paradoxographer, the second one from Palaephatus (cf. Hugo Koning's chapter in this volume); see the third section below for references. 
within the system from the start, while traditional versions of myths continue to live and flourish alongside. ${ }^{4}$ Traces of the tendency to explain and rationalize myth can already be found in early prose authors like Hecataeus (sixth century BCE), Prodicus, and, of course, Herodotus. Critical remarks about myth rationalization in Euripides and Plato show that it was a relatively well-known phenomenon in the fifth and fourth centuries BCE. ${ }^{5}$ The first extant author who participated in myth rationalization in a systematic way was Palaephatus, who wrote in the late fourth century вСE. Hawes traces the tradition of myth rationalization forward in time, via Euhemerus, Conon, and Plutarch to the work of Pausanias and Heraclitus in the second century CE. ${ }^{6}$ Before turning to Palaephatus, ${ }^{7}$ I will illustrate the practice of myth rationalization with a passage from Pausanias, Lucian's contemporary.

Pausanias' Periegesis is of course much more than just myth rationalization, but explanations of myths are a recurring feature of the work. One example is his account of Boeotia, where he explains the well-known story of the spring of Narcissus as follows $(9 \cdot 31 \cdot 7-8):{ }^{8}$

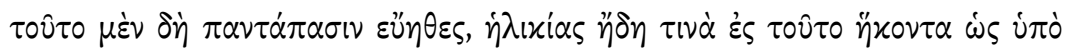

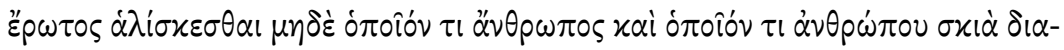

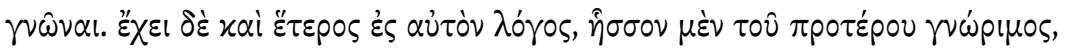

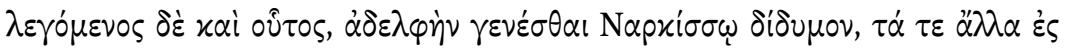

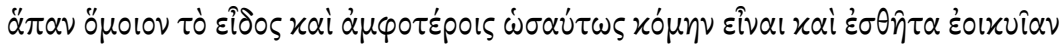

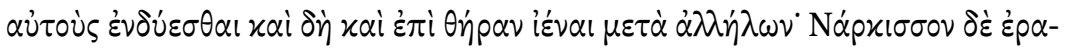

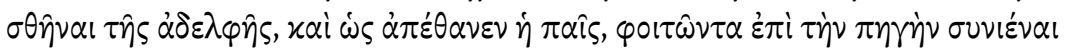

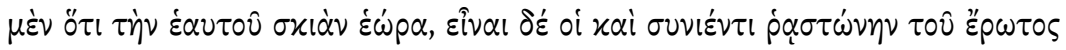

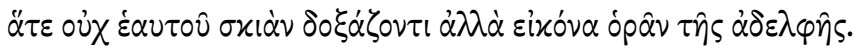

4 Hawes 2014, 223-225; cf. Pirenne-Delforge 2009, 39sq. (this text is adapted from Pirenne-Delforge 2008, 64-86); Hunter 2016.

5 In Pl. Phdr. 229c-23oa Socrates dismisses a rationalization of a myth about Boreas as ärpowxós

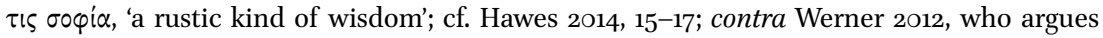
that Socrates is talking about allegory instead of myth rationalization in this passage, and Brouwer 2014, who disputes that Socrates is being critical of rationalization; on the distinction between allegory and rationalization see Hawes 2014, 28-35. At E. Ba. 286-297 Teiresias explains the myth of Dionysus' birth from Zeus' thigh through far-fetched, rationalizing wordplay; the whole scene seems parodic in nature, cf. Segal 1997, 280; Hawes 2014, 14sq.

6 Hawes 2014, 6-13. On rationalization in Plutarch, specifically of underworld myths, see also Hilton 2019.

7 On Palaephatus and aetiology see also the chapter by Hugo Koning in this volume.

8 The story is told in great detail at Ov. Met. 3.339-508; on the myth in general see Nelson 2000. 
It is utter stupidity to imagine that a man old enough to fall in love was incapable of distinguishing a man from a man's reflection. There is another story about him, less known than the previous one, but told also nonetheless. Narcissus had a twin sister, they were exactly alike in appearance, they had the same hair and wore the same clothes, and they even went hunting together. Narcissus fell in love with his sister, and when the girl died, he would go to the spring. Though he knew that he saw his own reflection, it was still some relief of his love-pains for him to think that he saw not his own reflection, but the image of his sister. ${ }^{9}$

For Pausanias the idea that an adult man could mistake his own reflection for someone else defies common sense. He retains, though, the basic idea that there is a spring in Boeotia where these events played out that one can visit in present time, and that the transmitted knowledge about the location of this spring is accurate. The rationalization cited by Pausanias here introduces instead a twin sister looking identical to Narcissus into puberty, arguably replacing one incredible story element with an equally unlikely narrative twist. Although Pausanias cites not his own but someone else's rationalization here, ${ }^{10}$ he does so seemingly with approval, and elsewhere he does offer original rationalizations. ${ }^{11}$

The narrative of the piece Electrum by Lucian follows a similar structure as Pausanias' account of the spring of Narcissus: someone travels to the site of a famous mythological event, and uses the opportunity to reflect on the plausibility of said event. But in fact, I suggest, Electrum functions as humorous criticism of the type of rationalist inquiry that Pausanias, whose work Lucian was likely familiar with, ${ }^{12}$ and others represent. The piece starts out as follows (Electr. 1):

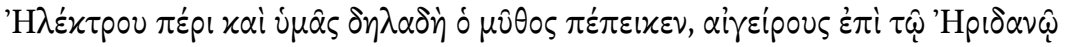

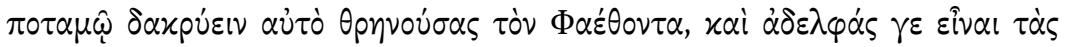

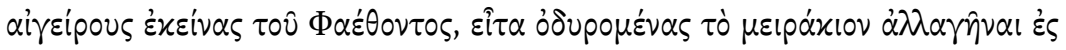

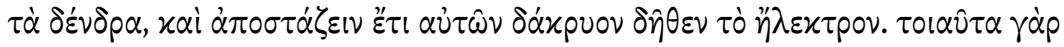

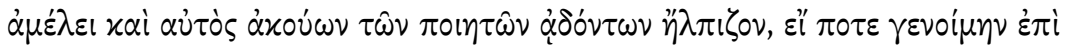

9 Translations throughout are my own unless stated otherwise. For Pausanias' text I follow the Teubner edition of Rocha-Pereira.

$10 \quad$ Nelson 2000, 370, n. 23; cf. Hawes 2014, 197.

11 On these see Veyne 1988, 95-102, and further discussion below.

12 Hutton 2005, 201sq.; cf. Pretzler 2013, 27, 103. 


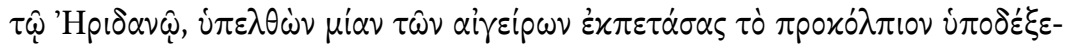

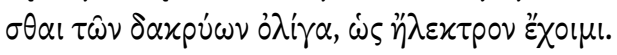

About amber you too clearly have been convinced by the story that the poplars off the Eridanos river shed tears of it mourning Phaethon, and that those poplars are the sisters of Phaethon, who out of sorrow for the boy were changed into trees, and that their tears still drip with amber. Such tales indeed I heard myself from the singing poets and I hoped, if I ever should get to the Eridanos, to catch some of these tears, standing under one of the poplars and stretching out a fold of my cloak, so that I would have amber. ${ }^{13}$

The narrator continues to say that he happened to be at the Eridanos recent$l y,{ }^{14}$ and had a chance to verify this aetiology himself. As it turns out there was no amber to be found, there were no poplars to be seen, and the locals had not even heard of the name Phaethon (Electr. 2). ${ }^{15}$ Lucian's first person narrator is measuring an element from the Phaethon myth by the standards of a historiographer dedicated to autopsy: if Phaethon's sisters were indeed turned into poplars crying amber, these trees must still be there today. The use of the word 'clearly' ( $\delta \eta \lambda \alpha \delta \eta$ ) in the first sentence signals that the speaker is not to be taken seriously. It is not at all clear that anybody but the narrator would invest the Phaethon myth with such factual accuracy as to expect material gain from it. Lucian ridicules the fruitless rationalist quest of our narrator from the start.

After finding out that the locals have not even heard of Phaethon the narrator tells them (and by extension the audience) the myth. The locals respond saying that they have not seen anyone falling from a chariot, and that they do not have the amber-shedding poplars. The narrator, he says, became ashamed

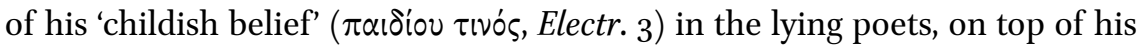
disappointment in being cheated out of the amber. The answers from the locals underline the naiveté of the narrator: he accepts their statement that

13 For Lucian's texts I follow the Loeb editions, which are generally preferred over the OCT.

14 The Eridanos is a somewhat elusive river, but typically understood as the Po (Plin. Nat. 37.11); cf. Ahl 1982, 394sq. Lucian locates the Eridanos in Italy at Salt. 55. For a full account of the amber story as connected to Phaethon see Ov. Met. 2.340-366. Apollonius Rhodius also tells the story at 4.596-618.

15 Ahl 1982, 394sq. writes that amber may have been transported from northern Europe to the Adriatic via the Po, but did not originate there. Plutarch in De sera numinis vindicta mentions that the people living on the banks of the Po put on mourning once a year in honor of Phaethon (Moralia 557d), but according to Pliny Phaethon died in Ethiopia, where there is a temple, an oracle, and amber production in his honor (Nat. 37.11); cf. van der Sluijs 2008, 228. 
they have not seen Phaethon fall out of the sky as damning proof against the Phaethon myth, failing to make the distinction between the heroic (mythical) and human eras. Even though in the rationalizer's outlook there is continuity between mythical and historical time - this is why it is reasonable to test myths against contemporary standards of plausibility - Phaethon's generation lived a long time prior to the narrator's. ${ }^{16}$ Based on his frame of reference the devoted rationalist can aim at finding material traces of events from myth, but even he should not expect to be able to track down eyewitnesses. Lucian's narrator is a caricature of a myth rationalizer.

The persistent narrator of Electrum proceeds to look into another aetiology connected with the Eridanos: that by this river Apollo turned some singers into swans, which explains the birds' melodious song (Electr. 4). The locals again disappoint, saying that the swans of the Eridanos croak in an 'unmusical and

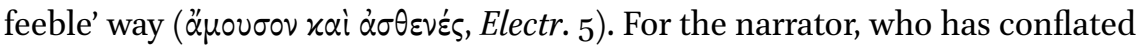
the role of swans as birds of Apollo with the aetiology about Phaethon's lamenting friend Cycnus (Kúxvos, which means 'swan') being turned into a swan by the same god, ${ }^{17}$ the locals' report means that the aetiology must be dismissed. Pausanias offers a seemingly more productive rationalization of the metamorphosis of Cycnus into a swan, when he suggests that the aetiology arose because a king with musical abilities who shared his name with swans ruled

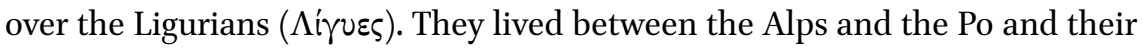
name in Greek is, aside from accentuation, indistinguishable from the adjective 'clear-voiced' ( $\lambda$ irús). This much Pausanias is willing to 'believe' ( $\pi \varepsilon^{\prime} \theta_{0 \mu \alpha l)}$ ), but that a man was turned into a bird he finds 'unbelievable' ( $\alpha$ $\pi / \sigma \tau \circ v, 1.30 .3) .{ }^{18}$ Pausanias and Lucian's narrator share the same approach: they are trying to salvage what they can from aetiological myth, using autopsy and reasoning to test these stories. In caricature form the myth rationalizer is frustrated because of his search for and reliance on eyewitnesses; Pausanias' honest attempt gives us an etymologizing aetiology for the myth that leaves us, however, none the wiser about swans, and why (or if) they are good singers.

In the last section of Electrum the narrator changes the topic, and his search for amber takes on a different function. He says that he fears first time audience

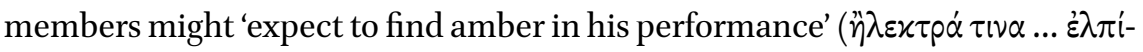

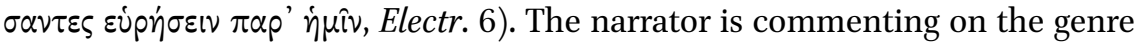
of the upcoming piece: his performance is not going to be poetry, and it will

\footnotetext{
16 On the issue of time and chronology in relation to aetiology see Walter 2020.

17 Cf. Nesselrath 1990, 125-129. Lucian refers to swans as having beautiful voices also at Bacch. 7 and $V H$ 2.15. For the Cycnus story see also Ov. Met. 2.367-38o.

18 Cf. Ahl 1982, 389; Hawes 2014, 202.
} 


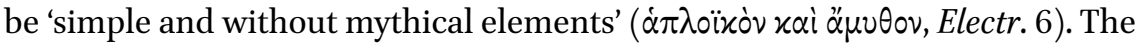
quest to find material evidence of myth is compared to the (potential) mistake of audience members who expect highfalutin poetry from the performance of a Lucianic piece. The underlying message is that a rationalist attitude towards myth is erroneous, because it looks for historical plausibility and likelihood in a genre that deals with a different kind of truth. Myth rationalizers make a genre mistake by asking the wrong kinds of questions of myth.

As we have already seen, a popular component of rationalization was to explain a myth through wordplay and (quasi-)etymology. Palaephatus explains mythical animals and monsters through names: Pasiphae fell in love with a handsome man named Taurus (Palaeph. 2); a man of the same name also abducted Europa (Palaeph. 15); Phrixus and Helle were not saved by a ram, but by a man named Ram who built a ship for them (Palaeph. 30). Lucian ridicules this kind of etymologizing rationalization of myth in his Muscae encomium, a mock encomium of the fly $(\mu \nu i \alpha) .{ }^{19}$ The anonymous first-person speaker explains the origin of the fly by a story of a girl named Fly or Muia, who lived long ago, and was 'very pretty, but garrulous, talkative, and fond of singing'

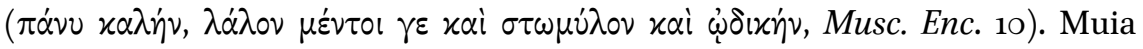
became a rival of Selene by falling in love with Endymion, a young man blessed with everlasting sleep, and Selene turned her into a fly, writes Lucian; flies still bother sleepers, particularly young and beautiful ones, in remembrance of Endymion (Musc. Enc. 10). The story of Muia is not otherwise attested, and Lucian likely made it up himself. ${ }^{20}$

The Muia-etymology parodies both the etymologizing myth rationalizations based on names that we find in Palaephatus and Pausanias, as well as aetiological myths that are based on etymology and onomastics. Just as in the myth rationalizations, Lucian's speaker methodically transfers the characteristics from the person Muia to the fly: in Palaephatus Taurus is very beautiful just like the bull in the myth; in Pausanias' slightly more complex etymology the musical king Cycnus rules over the 'clear-voiced' Ligurians, while in the myth the swan is clear-voiced. In Lucian's piece much humour is derived from the lowliness of the subject, but the distorted causality that underlies the idea that

19 Compare Dio Chrysostom's encomia of the parrot (Philostr. VS 1.7) and the gnat (Synes. Dio 3.81); among Libanius' Progymnasmata encomia of Thersites (4) and of the ox (8) have been transmitted (nos. as in Gibson 2008). On this genre see Pease 1926; cf. Hopkinson 2008, 142sq.

20 In Apollodorus (1.7.5) Endymion uses his wish granted by Selene to ask for eternal sleep, and Zeus fulfills it; there is no reference to the wish in Pausanias (5.1.3-5) or Apollonius (4.57-58 with scholia ad loc.); cf. Hopkinson 2008, 149. The Muia-story is reminiscent of Hera's turning Io into a heifer. 
flies bother sleepers in remembrance of Endymion suggests that Lucian was taking aim at etymologizing myth rationalizers as well.

\section{$3 \quad$ Lucian and First Inventors}

In the fragments of the philosopher Prodicus the origins of religion are explained, in part, by the fact that the first (human) inventors of crafts needed for survival came to be considered as gods. ${ }^{21}$ Under the influence of Prodicus' ideas Palaephatus and later Euhemerus frequently explained mythical narratives using the so-called first inventor motif, in which a god or hero is interpreted as the first human inventor of a certain instrument or skill. Because of the novelty of their creation these inventors then came to be considered as supernatural beings. ${ }^{22}$ Palaephatus, for instance, argues that the centaurs invented horseback riding, but appeared from a distance to be horse-men, causing the myth (Palaeph. 1). In another example he writes that Medea did not rejuvenate men by boiling them, but rather was the first to use hair dye, and to understand the benefits of the steam bath (Palaeph. 43). ${ }^{23}$ In Lucian's time the first inventor motif, a device that is part of the larger practice of myth rationalization, is taken up again by Heraclitus the Paradoxographer. In his De incredibilibus (On Unbelievable Tales) the myth of Atlas is explained, for instance, as follows (Incred. 4):

O

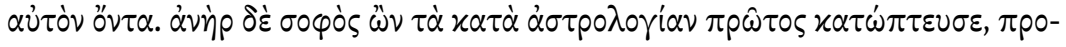

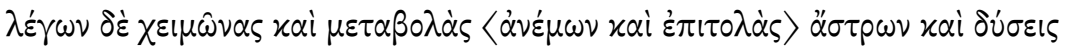

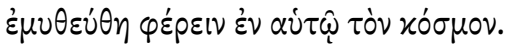

It is traditionally said that Atlas carries heaven on his shoulders, which is impossible, even though Atlas himself is under heaven. Atlas was a wise man who was the first to observe the principles of astronomy. He foretold

21 Henrichs 1975, 107-123; cf. Mayhew 2011, xvii-xviii, xxi-xxiii.

22 Euhemerus' name has become associated so closely with explaining gods as human inventors that this is sometimes referred to as 'euhemerizing'. An important difference between Euhemerus and Palaephatus is that the latter only deals with the myths of heroes and monsters, staying away from the gods, cf. Colpe 1995, 39-41; Winiarczyk 2002, 1-10, 107-118; Stern 2003, 51-71; Hawes 2014, 25-28.

23 According to Palaephatus Pelias' death after said 'steam bath' was due to his feebleness. For a full list of first inventors in Palaephatus see Stern 1996, 20sq. The centaur-rationalization also occurs in Heraclitus (Incred. 5); cf. Stern 2003, 64sq. 
storms and changes [in the winds and the risings] and settings of stars, and so the myth arose that he carried the cosmos within himself. ${ }^{24}$

The impossibility of Atlas being able to carry heaven on his shoulders is 'solved' by interpreting him as the inventor of astronomy. In this kind of a rationalization the first inventor motif fulfils a double duty: it explains the aetiology of a certain myth, and, as Hawes writes, it promotes "a particular area of knowledge through association with the cultural capital of myth". ${ }^{25}$

When Lucian turns his attention to the first inventor motif he criticizes both functions, promotional as well as explanatory. The passages that I will discuss are taken from three different texts: De astrologia, De saltatione, and De parasito. ${ }^{26}$ In these pieces Lucian, again, plays with the genre of encomium, and he takes on myth rationalization's first inventor motif using ridicule, exaggeration, and subversion. To start, I will return to Simon's defence of parasitism from which this chapter takes its title. De parasito is a discussion between Tychiades and the self-professed professional parasite Simon on whether being a parasite is a techne or not. It is a parody both of the quarrel between rhetoric and philosophy, and of philosophical debates on the definition of techne.. ${ }^{27}$

As we have seen, Simon enlists the heroes as the inventors of parasitism to bolster the antiquity and repute of the parasitic art; ${ }^{28}$ Nestor, Idomeneus, and Patroclus were parasites according to Simon. Tychiades pushes back against Simon's enlisting of Patroclus, and Simon turns to Homer to make his case: Patroclus said that he wanted his bones to be close to Achilles' corpse, because

24 This emendation was suggested by Festa in his 1902 Teubner edition, whose text I follow

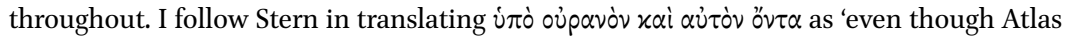
himself is under heaven': "Because' might seem a more likely translation, but the sense, I believe, is not as good" (Stern 2003, 93, n. 68). The same explanation of the Atlas-myth also occurs in Dionysius Scytobrachion (BNJ 32 F7.6o.2 = D.S. 3.6o.2), cf. Stern 2003, 75 . Heraclitus' explanation of Asclepius as an innovator who died not by Zeus' thunderbolt but of a high fever (26) does appear to be original.

25 Hawes 2014, 121.

26 The authenticity of all three pieces has been contested. Harmon 1921, 235 tentatively rejects De parasito, but Hall 1981, 334-339, Nesselrath 1985, 1-8, and Anderson 1979, 59-66 have accepted it, and it is now uncontroversial. Lightfoot 2003, 195 and McNamara 2013 understand De astrologia as authentic, contra Caster 1937, 26o-263; cf. Jones 1986, 170. De saltatione, disputed by Helm 1906, 369 sq., must be understood in the context of Lucian's association with the court of Verus who loved pantomime, cf. Anderson 1977; Jones 1986, 68-75.

27 For examples of such debates and their relevance to De parasito, see Hall 1981, 331-334; cf. Nesselrath 1985, 123-230.

28 Compare the notion that Homer's Nestor and Odysseus were the first orators, see e.g. D.Chr. 2.20, cf. Nesselrath 1985, 433-444. 
he was 'nourished' in his house ( $\dot{\tau} \rho \alpha \dot{\alpha} \varphi \eta \nu, I l .23 .84$ ). Further, Patroclus said that

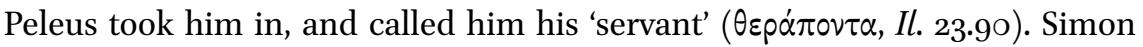
continues (Par. 47):

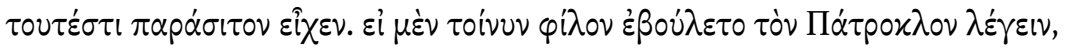

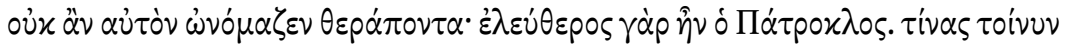

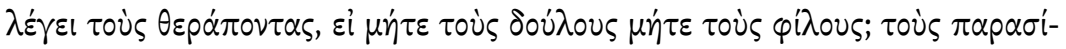

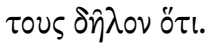

That is, he [Peleus] maintained him as a parasite. If he had wanted to call Patroclus a friend, he would not call him a servant, for Patroclus was a free man. Whom, then, does he mean by servants, if neither slaves nor friends? Clearly, parasites.

Lucian's Simon takes the familiar ancient debate about Patroclus' status in relation to Achilles, and repurposes it for a first inventor story that purports to provide a legitimizing aetiology for the parasitic art. ${ }^{29}$ Again, because the parasitic art is so unlikely as a techne, any attempt to make it one is humorous. Simon's flimsy argumentation for the claim that Patroclus was a parasite, and thereby one of the first inventors of the art, pushes the piece into the realm of parody.

De saltatione takes as its subject the merits of pantomime, the hugely popular silent dance that was frequently assailed by orators in the imperial period. ${ }^{30}$ Unlike De parasito it cannot be read as a mock-encomium because of its historical context: it was probably written for emperor Lucius Verus who loved pantomime ${ }^{31}$ Nonetheless, the piece does appear to have some humorous elements, notably a complete, parodic version of a first inventor rationalization offered by the interlocutor Lycinus (Salt. 19):

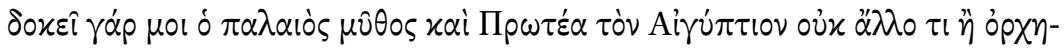

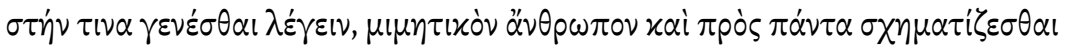

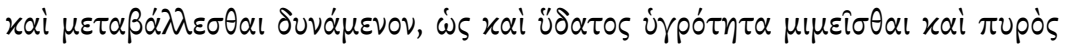

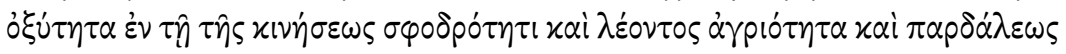

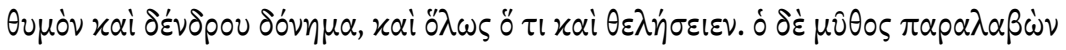

29 On Achilles and Patroclus see e.g. Pl. Smp. 18oa-b.

30 Molloy 1996, 86-100; cf. Lada-Richards 2007, 68sq., 92sq., 104-112; Webb 2008, 62-92, 140sq.; Bowersock 2008, 69-77.

$31 \quad$ See n. 26. 


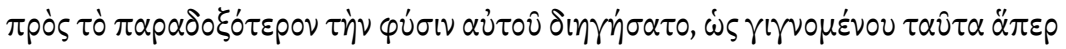
$\dot{\varepsilon} \mu \mu \varepsilon \varepsilon i \tau 0^{-1}$

I think that the ancient myth about Proteus the Egyptian means nothing else than that he was a dancer, an imitative man and capable of shaping and changing himself into anything, even the liquidity of water and the sharpness of fire, through the expressiveness of his movement, and also the fierceness of the lion, the rage of the leopard, and the waving of the tree, so on the whole, whatever he wished. Myth in taking on the tradition described his nature more paradoxically, that he became whatever he imitated.

Lycinus closely follows the traditional model of myth rationalization through the first inventor motif: he starts from the traditional myth, proposes his own, improved explanation, and concludes by analyzing how the erroneous myth arose. Following this rationalization Lycinus makes explicit his purpose of glorifying the human technē by giving it a mythical forefather: contemporary pantomime dancers follow in Proteus' footsteps when they seemingly become the characters they imitate, ${ }^{32}$ Lycinus adds that the story of Empusa, a monstrous ghost who could assume different forms, can also be explained by her having been a dancer (Salt. 19). ${ }^{33}$ This casual addition of Empusa to the rationalization of the Proteus myth, in my view, tips the passage as a whole into the realm of satire. Lucian underlines the opportunism of simultaneously bending myth to fit a rationalizing framework and elevating human innovations by giving them mythical progenitors. ${ }^{34}$ Proteus and Empusa as the 'original' pantomime dancers work well as parodies of the stories of Medea the beautician and Atlas the astrologer.

Our final examples of the first inventor motif in Lucian come from $D e$ astrologia, a mock-encomium of astrology. ${ }^{35}$ Strikingly, some of these mock rationalizations were taken over by a fifth century CE anonymous author to

32 Libanius (Or. 64.117) and Aristaenetus (1.26.11-12) compare dancers to Proteus, but without offering the myth rationalization, cf. Molloy 1996, 272; Lada-Richards 2007, 185, n. 43 .

33 See e.g. Ar. Ra. 294.

34 On the humour of this passage cf. Anderson 1977, 279; contra Lawler 1943, 116sq., who connects Lycinus' explanation to an old ritual dance performed by priests to portray mimetically concepts like wind or fire.

35 I follow McNamara 2013 in reading the piece as a caricature of a Stoic philosopher overly dedicated to astrology; contra Spickermann 2013, 150 who strains to reconcile De astrologia with the often humorous attitude toward ancient religious practice of Lucian's corpus. 
be used in a catalogue of serious myth rationalizations, titled De incredibilibus (just as the work of Heraclitus the Paradoxographer). Lucian's speaker begins with Orpheus, who enthralled his followers not through music, but through his (imperfect) first attempts at astrology (Astr. 10). Next, Tiresias was not both male and female, but he was the first to observe the difference between wandering female and male stars (Astr. 11). Thyestes did not have a golden ram, but he was the first to point out the constellation Aries (Astr. 12). A rationalization of the Bellerophon story follows, which was borrowed by the anonymous paradoxographer; I give Lucian's version here (Astr. 13):

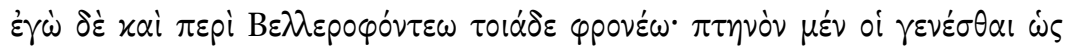

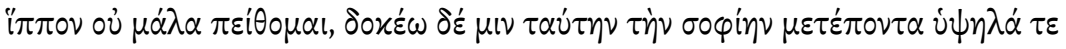

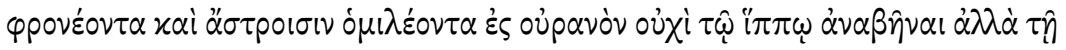
Siavoín.

I think the following about Bellerophon as well: I do not at all believe that he had a winged horse, but I think that, pursuing this knowledge [i.e. astrology, IK], contemplating the things up high, and communing with the stars, he reached heaven not by means of his horse but through his intelligence. ${ }^{36}$

The fact that the anonymous author could borrow from Lucian's text with hardly any alteration illustrates well the difficulty scholars have had in interpreting De astrologia. ${ }^{37}$ On the level of the paragraph the narrator's rationalization of Bellerophon as astrologer can well appear 'straight': the anonymous paradoxographer saw no harm in using it, and several other passages from the same piece, for his earnest, scholarly purposes. ${ }^{38}$ But the accumulation of first inventors and early adopters of astrology, as well as some very tenuous explanations, make the rationalizing section as humorous as the rest of the work.

The speaker of De astrologia follows his account of Bellerophon with mentions of the astrologers Phrixus (Astr. 14) and Daedalus (Astr. 14-15). Probably the most far-fetched explanation is reserved for the Pasiphae myth: she, having heard from Daedalus about the constellation Taurus and about astrology,

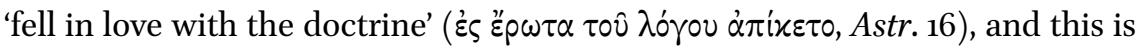

36 Cf. anon. Incred. 14 (Greek text in Festa 1902, 94); translation in Hawes 2014, 244.

37 See n. 26 and n. 35 .

38 Further borrowings are Incred. $13=$ Astr. 19; Incred. $15=$ Astr. 15; Incred. $19=$ Astr. 21 ; cf. Hawes 2014, 120-123, 244, 247. 
why people believe that Daedalus assisted in the wedlock of Pasiphae and the bull. The speaker now says that among all these early astrologers 'each made different discoveries, as they dissected the science into parts' ( $\varkappa \alpha \tau \dot{\alpha} \mu \varepsilon \dot{\rho} \rho \varepsilon \alpha \dot{\eta} \nu$

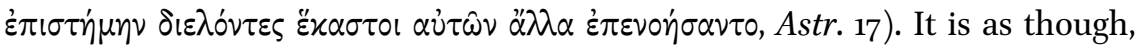
after the rather unlikely interpretation of the Pasiphae story, he is answering a tacit complaint from the audience, namely: 'Are you really going to argue that every mythical character invented astrology?'

The speaker, in fact, only has two more astrologers in store: Endymion, he says, established the motions of the moon (Astr. 18), while Phaethon put together the course of the sun, although he left the theory incomplete at his death (Astr. 19). According to the speaker most people are ignorant of Phaethon's contribution, and this is why they believe the traditional myth, but, he adds, 'these things did not happen in this way, and it is not pious to believe

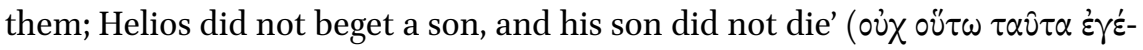

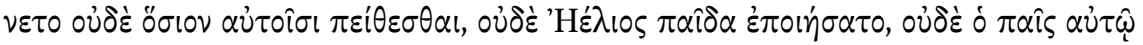
$\dot{\alpha} \pi \dot{\varepsilon} \theta \alpha \nu \varepsilon v$, Astr. 19). ${ }^{39}$ Lucian depicts the speaker as being so zealous in refuting the traditional myths that he starts to contradict himself: if Helios did not have a son, how could this son not have died? The speaker's disappointment that people are ignorant of the fact that Endymion and Phaethon were astrologers is equally damning. People do not know this, because it is absurd.

In De astrologia Lucian lampoons all the elements that constitute the first inventor motif: an explanation of how the erroneous myth came about, tenuous connections between the myth explained and the specific invention, a one size fits all approach whereby one and the same invention can be used to explain numerous mythological narratives, and the attempted elevation of a particular invention by citing as many mythical progenitors as possible. We found a similar parodic approach to this myth rationalization device in De parasito and De saltatione, but De astrologia is clearly the fullest expression of Lucian's satirical treatment of the first inventor motif. Through exaggeration and overuse he renders this particular mode of explaining the origins of myth ridiculous. ${ }^{40}$

39 McNamara 2013, 245 interprets this sentence as meaning that "the sun never begets children and even if it did, such a son his [sic] would not have died in this way". This seems an overly sympathetic reading of the narrator's much simpler phrase.

40 Lucian also takes aim at the first inventor motif in his Podagra (Gout), where a silly number of figures of myth are said to have suffered from gout, though not Cronus (Pod. 248262); cf. Whitmarsh 2013, 185, see further below. 
The rationalist attitude toward myth subjects the stories of myth, some of them also aetiological, to the aetiological mode of explanation, asking the question of where these myths came from. Myth rationalization responds to the problem that by the standards of plausibility of systematic inquiry many mythological narratives are problematic. During the Second Sophistic perhaps more than at any other time being Greek, or being Roman for that matter, meant being fluent in the language of Greek mythology, which is why problematic myths could not simply be brushed aside. In order to preserve and perpetuate these mythological stories salvageable elements are put into a new mould of causality. If the myth as it is cannot be maintained as a causal narrative in its own right, at the very least myth rationalizers want to explain what the cause of the myth was. The first inventor motif takes this process one step further, by using the rationalized and revised myths as aetiologies not only for the original myths, but also for familiar crafts and inventions. Lucian's parodies aim to show that rationalizers make a category mistake in applying proto-scientific methodologies from historiography or medicine to myth. Through their attempts they destroy the non-discursive, imaginative truth offered by myth. The first inventor motif is even more problematic in that it produces, under the pretext of systematic reasoning, aetiological narratives that are, at best, as problematic as the myths they try to explain, or, at worst, completely foolish. For Lucian it is better to play with myth through humour, than to ruin it by fruitlessly looking for its causes.

In his Saturnalia Lucian has Cronus rationalize his own myth. According to the god people erroneously assume that Zeus put him in chains, because his movements became restricted in his old age by gout (Sat. 7). In one blow Lucian one-ups rationalizers of myth by having more fun with the material, and parodies their methods by putting them in the hands of Cronus.

\section{Bibliography}

Ahl, F. (1982). Amber, Avallon, and Apollo's Singing Swan. American Journal of Philology, 103(4), pp. 373-411.

Anderson, G. (1977). Lucian and the Authorship of De saltatione. Greek, Roman and Byzantine Studies, 18(3), pp. 275-282.

Anderson, G. (1979). Motifs and Techniques in Lucian's De parasito. Phoenix, 33(1), pp. 59-66. 
Bowersock, G. (2008). Aristides and the Pantomimes. In: W. Harris and B. Holmes, edd., Aelius Aristides between Greece, Rome, and the Gods. Leiden/Boston: Brill, pp. 69-77.

Brouwer, R. (2014). The Stoic Sage. The Early Stoics on Wisdom, Sagehood, and Socrates. Cambridge: Cambridge University Press.

Caster, M. (1937). Lucien et la pensée religieuse de son temps. Paris: Les Belles Lettres.

Colpe, C. (1995). Utopie und Atheismus in der Euhemeros-Tradition. In: M. Wacht, ed., Panchaia. Festschrift für Klaus Thraede. Münster: Aschendorff, pp. 32-44.

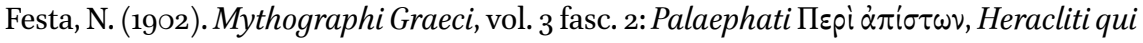

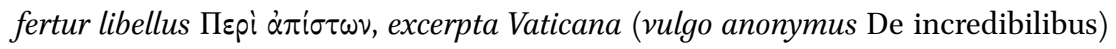
Leipzig: Teubner.

Gibson, C. (2008). Libanius's Progymnasmata. Model Exercises in Greek Prose Composition and Rhetoric. Atlanta: Society of Biblical Literature.

Hall, J. (1981). Lucian's Satire. New York: Arno Press.

Harmon, A. (1921). Lucian, vol. 3. Cambridge, Mass.: Harvard University Press.

Hawes, G. (2014). Rationalizing Myth in Antiquity. Oxford: Oxford University Press.

Helm, R. (1906). Lucian und Menipp. Leipzig: Teubner.

Henrichs, A. (1975). Two Doxographical Notes. Democritus and Prodicus on Religion. Harvard Studies in Classical Philology, 79, pp. 93-123.

Hilton, C.M. (2019). Epicurean Myth Rationalization in Plutarch's De latenter vivendo and Lucretius' Catalogue of Underworld Torments. Greek, Roman and Byzantine Studies, 59(1), pp. 134-157.

Hopkinson, N. (2008). Lucian. A Selection. Cambridge: Cambridge University Press.

Hunter, R. (2016). 'Palaephatus,' Strabo, and the Boundaries of Myth. ClassicalPhilology, $111(3)$, pp. $245^{-261 .}$

Hutton, W. (2005). Describing Greece. Landscape and Literature in the Periegesis of Pausanias. Cambridge: Cambridge University Press.

Jones, C. (1986). Culture and Society in Lucian. Cambridge, Mass.: Harvard University Press.

Lada-Richards, I. (2007). Silent Eloquence. Lucian and Pantomime Dancing. London: Duckworth.

Lawler, L. (1943). Proteus is a dancer. The Classical Weekly, 36(10), pp. 116-117.

Lightfoot, J. (2003). Lucian. On the Syrian Goddess. Oxford: Oxford University Press.

Mayhew, R. (2011). Prodicus the Sophist. Texts, Translations, and Commentary. Oxford: Oxford University Press.

McNamara, C. (2013). Stoic Caricature in Lucian's De astrologia. Verisimilitude as Comedy. Peitho. Examina Antiqua, 1(4), pp. 235-253.

Molloy, M. (1996). Libanius and the Dancers. Hildesheim: Olms-Weidmann.

Nelson, M. (2000). Narcissus. Myth and Magic. Classical Journal, 95(4), pp. 363-389.

Nesselrath, H.-G. (1985). Lukians Parasitendialog. Untersuchungen und Kommentar. Berlin/New York: De Gruyter. 
Nesselrath, H.-G. (1990). Lucian's Introductions. In: D. Russell, ed., Antonine Literature. Oxford: Clarendon Press, pp. 111-140.

Pease, A. (1926). Things without Honor. Classical Philology, 21(1), pp. 27-42.

Pirenne-Delforge, V. (2008). Retour à la source. Pausanias et la religion grecque. Liège: Centre International d'Étude de la Religion Grecque Antique.

Pirenne-Delforge, V. (2009). Under Which Conditions Did the Greeks 'Believe' in Their Myths? The Religious Criteria of Adherence. In: U. Dill and C. Walde, edd., Antike Mythen. Medien, Transformationen und Konstruktionen. Berlin/Boston: De Gruyter, pp. 38-54.

Pretzler, M. (2013). Pausanias. Travel Writing in Ancient Greece. London: Bristol Classical Press.

Segal, E. (1997). Dionysiac Poetics and Euripides' Bacchae, 2nd, expanded ed. Princeton: Princeton University Press.

Sluijs, M. van der (2008). On the Wings of Love. Journal of Ancient Near Eastern Religions, 8(2), pp. 219-251.

Spickermann, W. (2013). Lucian of Samosata on Oracles, Magic and Superstition. In: V. Rosenberger, ed., Divination in the Ancient World. Religious Options and the Individual. Stuttgart: Steiner, pp. 139-151.

Stern, J. (1996). Palaephatus. On Unbelievable Tales. Wauconda: Bolchazy-Carducci.

Stern, J. (2003). Heraclitus the Paradoxographer. Пвpi $\alpha \pi i \sigma \tau \omega \nu$, On Unbelievable Tales. Transactions of the American Philological Association, 133(1), pp. 51-97.

Veyne, P. (1988). Did the Greeks Believe in their Myths? An Essay on the Constitutive Imagination [French orig.: Les Grecs ont-ils cru à leurs mythes? Essai sur l'imagination constituante 1983]. Chicago: University of Chicago Press.

Walter, A. (2020). Time in Ancient Stories of Origin. Oxford: Oxford University Press.

Webb, R. (2008). Demons and Dancers. Performance in Late Antiquity. Cambridge, Mass.: Harvard University Press.

Werner, D. (2012). Myth and Philosophy in Plato's Phaedrus. Cambridge/New York: Cambridge University Press.

Whitmarsh, T. (2013). Beyond the Second Sophistic: Adventures in Greek Postclassicism. Berkeley: University of California Press.

Winiarczyk, M. (2002). Euhemeros von Messene. Leben, Werk und Nachwirkung. Munich/Leipzig: K.G. Saur. 